\title{
Organic and conventional date farm efficiency estimation, and its determents at Riyadh province, Kingdom of Saudi Arabia
}

\author{
S. H. Alkahtani \& A. M. Elhendy \\ Agriculture Economic Dept., College of Food Sciences and Agriculture, \\ King Saud University, Saudi Arabia
}

\begin{abstract}
This paper aims to estimate efficiencies of input use and its determinants using a two step methodology. First, to estimate the efficiency of conventional and organic date farms in Saudi Arabia, with special reference to the Riyadh province. Second, to show the impacts of relative input use, as an indicator of technology level and specialization degree, as efficiency determinants. Riyadh Province has the main date production and date area, it reaches $23 \%$ and $25 \%$ of total production and area of dates respectively. It is also a province which is characterized by most of the organic date farms in the Kingdom.

Technical, cost, and scale efficiencies are estimated using Data Envelopment Analysis (DEA) approach, for 82 conventional and 49 organic date farms. The study results show that $22 \%$ of conventional date farm technical efficiency have a range of $50-59 \%$, while $32 \%$ of them have a cost efficiency range of $40-49 \%$. Technical and cost efficiency ranges were $50-59 \%$ and $20-29 \%$ for $29 \%$ and $39 \%$ of organic date farms respectively.

The efficiency measures are regressed, using Tobit Model, on a set of explanatory variables which includes efficiency determinants such as water, labor, per hectares. The significant relationship between farm use of water per hectare, as the most scarce resource, and scale efficiency is negative in the case of conventional and organic date farms, i.e. less water use increases scale efficiency. Date farm area relative to total farm area has a positive impact on date farm efficiency. A negative impact of labor, per hectare, on efficiency reflects the importance of applying modern agriculture which required less labor and more technology.
\end{abstract}

Keywords: productivity, efficiency, data envelopment analysis, Tobit model. 


\section{Introduction}

Recent developments in agriculture have stirred up interest in the concept of "sustainable" farming systems. Still it is difficult to determine the extent to which certain agricultural practices can be considered sustainable or not. Aiming at identifying the necessary attributes with respect to sustainability, this paper focused on estimating "distance" between organic and conventional farming. The majority of studies of agricultural productivity in developing countries support the view that there is an inverse relationship between efficiency (productivity) and farm size. If correct, land reform could contribute to improving both productivity and efficiency in agriculture. Most of these studies, however, are based on partial measures of productivity such as average yield and revenues, which are biased in favor of small producers. Dates is the most important crop in Saudi Arabia, as its area increased from 142 to 162 thousand hectares through 2000 to 2009, no other crop has that area. Its production increased from 734 to 991 thousand tons at the same period. Riyadh province, as one of thirteen provinces in the Kingdom, had about $25 \%$ of total area and production in 2000 , but in 2009 its relative importance of production decreased to $23 \%$, even its share in total area increased to $27 \%$. So, Technical and cost efficiency of date farms, and its efficiency determents for both conventional and organic date farms became a necessary step to develop date production sector. This paper explores the relationship between, farm input use, technical and cost efficiency with special reference to conventional and organic date farms. A second objective of this paper is to extend the recent analysis to show the impacts of efficiency determinants of date farms. To analyze the determinants of technical, cost, and scale efficiencies in an econometric framework, using Tobit model. Efficiencies parameter estimates, as dependent variables, are regressed on a set of explanatory variables which includes date area to total farm area, labor, water, and fertilizer, per hectares, as an indicator of technology level and relative input usage. In this paper, data from 82 conventional and 49 organic date farms are collected, and 3 categories of farm sizes which are greater than $30,30-10$, and less than 10 hectares, are used.

The paper is organized as follows. Section 2, briefly presents the Data Envelopment Analysis (DEA) methodology, that is used to estimate technical, cost, and scale efficiencies. Section 3, describes the data sources and the construction of the variables of the model. Section 4, analyzes the empirical results, with an emphasis on the efficiency determents, and section 5, provides study conclusions.

\section{Methodology}

The measurement of productive efficiency has important implications for both economic theory and economic policy (Farrell [1]). Measuring productive efficiency allows one to test competing hypotheses regarding sources of efficiency or differentials in productivity. Moreover, such measurement enables us to quantify the potential increases in output that might be associated with an 
increase in efficiency. Efficiency measurement is typically implemented by either an econometric or mathematical programming approach. The latter, commonly referred to as Data Envelopment Analysis (DEA), is pursued here. DEA is a nonparametric method and has the advantage that it does not impose a functional form on the production function (Färe et al. [2], Ray [3]). However, this approach has two disadvantages: it does not allow direct hypothesis testing (Ray [3]) and derived measures of inefficiency are confounded with the effects of noise, measurement error, and exogenous shocks beyond the control of the production unit (Färe et al. [2] and Ray [3]).

The economic literature on production efficiency typically distinguishes two types of efficiency: technical efficiency and allocative efficiency. The latter includes as components cost minimization, revenue maximization, and profit maximization. A technically efficient firm is one that produces the maximum output for a given amount of inputs, conditional on the production technology available to it. An allocatively efficient firm applies the optimal amount of inputs to produce the optimal mix of outputs given the production technology and the prices it faces. A firm that is both technically and allocatively efficient is said to be economically efficient (Papadas and Dahl [4]).

In an early study, Carter [5] analyzed the inverse relationship between farm size and farm productivity in India and found differences between small and large farms that could not be explained by factors correlated with farm size. Carter showed that small farms were technically inefficient and, in addition, that small farms allocated labor beyond the optimal level defined by profit maximization at market prices. Using panel data from rice farms in the Philippines, Shively and Zelek [6] similarly argued that, from a profit maximization perspective, small farms over applied labor and under applied fertilizers and pesticides. Hoque [7] found that smaller farms were more efficient than larger farms in allocating labor but that larger farms were more efficient in allocating biological and chemical inputs. In contrast, Adesina and Djato [8] found small and large farms in Côte d'Ivoire to be equally efficient. They identified access to credit and use of modern varieties as factors correlated with agricultural profit.

Recent studies exploring the relationship of farm size and efficiency have used a two-step methodology. In the first step, efficiency measures are calculated. Then, efficiency measures are regressed on farm specific characteristics to identify sources of efficiency (see, for example, Tadesse and Krishnamoorthy [9]; Gilligan [10]; Shafiq and Rehman [11]; Fletschner and Zepeda [12]; Nyemeck et al. [13]). Efficiency is typically found to be correlated with farm-specific attributes such as farm size, input use ratio, the farm manager's education, land titling, access to credit, employment opportunities, land quality, agro-ecological zone, and extension services.

Following the traditional two-step analysis. In the first step, we calculate technical and cost efficiencies measures using DEA. In the second step, regressing these measures of technical cost, and scale efficiencies on a set of farm characteristics based on per hectare input use, which includes date farm size to the whole farm size, water, labor, fertilizer, farm yield, and revenue. The 
differences between yield and total revenues, as an independent variable, would show the impact of product values, especially with different output prices based on date varieties. Total Revenues and cost efficiency are important economic indicators for any type of farms.

\subsection{Efficiency measures}

In order to identify the technical efficiency of farms in our sample, we solve the following linear programming problem:

$$
\begin{array}{ll} 
& \max y_{y, \lambda^{1}, \ldots, \lambda^{k}} \\
& \sum_{k=1}^{K} y^{k} \lambda^{k} \geq y \\
& \sum_{k=1}^{K} x_{n}^{0} \lambda^{k} \leq x_{n} \\
& \sum_{k=1}^{K} \lambda^{k}=1 \\
& \lambda^{k} \geq 0
\end{array}
$$

where $y$ is an optimal level of output, $y^{k}$ denotes the output of the $k^{\text {th }}$ farm, $x_{n}{ }^{k}$ denotes the level of the $n^{\text {th }}$ input used on farm $k, x_{n}^{0}$ is the $n^{\text {th }}$ input used on the farm whose efficiency is being tested, and $\lambda^{k}$ is the weight given to farm $k$ in forming a convex combination of the input vectors. The resulting technical efficiency index is calculated as a ratio between the observed level of output on the farm being tested $\left(y^{0}\right)$ and the optimal level of output $(y)$. Technically efficient farms are those with an efficiency index equal to one. Technically inefficient farms are those with an index strictly lower than one.

Cost efficient farms (under the assumption of variable returns to scale) are identified by solving:

$$
\begin{aligned}
& \min _{x_{1}, \cdots, x_{n}, \lambda^{1}, \ldots, \lambda^{k} \quad \sum_{n=1}^{t} w_{n}^{0} x_{n}} \\
& \sum_{k=1}^{K} y^{k} \lambda^{k} \geq y \\
& \sum_{k=1}^{K} x_{n}^{k} \lambda^{k} \leq x_{n} \quad \text { for } 1 \leq n \leq t \\
& \sum_{k=1}^{K} x_{n}^{k} \lambda^{k} \leq x_{n} \quad \text { for } n>t \\
& \sum_{k=1}^{K} \lambda^{k}=1 \\
& \lambda^{k} \geq 0
\end{aligned}
$$

where $w_{n}^{0}$ is the cost of the $n(n=1, \ldots, \mathrm{t})$ input faced by the farms whose efficiency is being tested, $\lambda^{k}$ is the weight given to farm $k$ in forming a convex 
combination of the output or input vectors, $x_{n}$ denotes the optimal amount of input $n(n=1, \ldots, \mathrm{t}), y^{\mathrm{k}}$ denote the output of farm $k(k=1, . ., \mathrm{K}), \lambda^{\mathrm{k}}$ is the weight given to farm $k, x_{n}^{k}$ denotes the level of input $n$ for firm $k$, and $x_{n}^{0}$ is the amount of fixed input $n$ on the firm whose efficiency is being tested.

The cost efficiency index is calculated as the ratio between the optimal cost $\left(w_{n} x_{n}^{l}\right)$ and the observed cost on the $k^{\text {th }}$ farm being tested $\left(w_{n} x_{n}^{0}\right)$. Cost efficient farms are those with a cost efficiency index equal to one. Farms with an index less than one are characterized as cost inefficient. Technical efficiency and cost efficiency indexes are relative measures, in the sense that they are obtained by comparing each farm to farms within a reference category.

\subsection{The determents impact on technical, cost, and scale efficiencies.}

Technical and cost efficiency indexes obtained using DEA are separately regressed on farm specific characteristics in order to identify sources of technical and cost inefficiency, respectively. Because efficiency measures range between 0 and 1, we employ a two-tailed Tobit model in place of OLS regression (Ray [3]). The Tobit model takes the following form:

$$
\operatorname{Index}_{k}^{*}=\beta^{\prime} X_{k}+u_{k}
$$

where Index ${ }_{k}^{*}$ is the value of the efficiency index obtained from DEA, $\beta$ is a vector of unknown parameters, vector $X_{k}$ contains independent variables hypothesized to be correlated with efficiency, and $u_{k}$ is an error term that is independently and normally distributed with mean zero and common variance $\sigma^{2}$.

\section{Data}

A total of 113 farmers, at 82 conventional and 49 organic date farms, which are equally distributed over the Riyadh province, were interviewed in 2010 . The survey obtained data required for achieving the study goals, including land use, date production, irrigation practices and management, input use levels such as labor, and organic and chemical fertilizer. In addition to farm yield and revenue, were surveyed farms produced dates of different varieties have different prices and revenues. Characteristics of these date farms are summarized in table 1. The average farm area is 41 and 25 hectares for both conventional and organic date farms respectively. Farms were classified according to the area into 3 categories. A farm with date area of 10 hectares or less is classified as a "small" date farm. In contrast, a farm with planted date area greater than 30 hectares is classified as a "large" farm. Medium size date farm area range between 10 and 30 hectares.

Outputs and inputs of the model are identified as following: Output (Y): The output variable is defined as the total production of date in ton. Total revenue (TR): value of output as total revenue in Saudi Rials (SR).

Farm area (X1): Total farm area in hectares, and date farm area (X11) are considered as the ratio of date farm area to total farm area (X11/X1). It is considered as a determinate of efficiency because it would be an indicator of the degree of date farming specialization. 
Labor (X2): Total number of farm workers is considered, and (X22) as number of labor per hectare, which is used as an indicator of technology level is estimated as the ratio of labor to date farm area.

Water (X3): Water is considered as the scarcest resource in the Kingdom, its total quantity per date farm is estimated with the average water used per hectare (X33), as another determinant of efficiency.

Organic and chemical fertilizers (X4), (X5): Organic fertilizers are used at both conventional and organic date farms because soil fertility is low, and chemical fertilizers are used only at conventional date farms. Average per hectare use of fertilizers, (X44) and (X55), are estimated as determinants of efficiency too.

A final step is the construction of the variables involved in creating "representative date farms" for each farm size, of each type of date farms, at Riyadh province. This is necessary, because there were 3 date farm size classes and 2 date farm types, organic and conventional. There were 82 and 49 conventional and organic date farms respectively.

Table 1 represents study data statistics, and the difference between conventional and organic date farms, for example average yield is 6.4 and 4.5 tons per hectare respectively. Average use of water at organic date farms, $16288 \mathrm{~m} 3 /$ hectare, is greater than that at conventional date farms, $14523 \mathrm{~m} 3 /$ hectare. Also, as expected, average sale price of dates were $9083 \mathrm{SR}$ and $13327 \mathrm{SR}$ per ton at conventional and organic date farms respectively. Organic fertilizer is used at rate of 70 and 102 tons per hectare for conventional and organic date farms.

Table 1: $\quad$ Characteristics of date farms, Riyadh province, 2010.

\begin{tabular}{|c|c|c|c|c|c|c|c|}
\hline $\begin{array}{l}\text { Conventional } \\
\text { Date Farms }\end{array}$ & $\begin{array}{l}\text { Total } \\
\text { Yield } \\
\text { (tons) }\end{array}$ & $\begin{array}{c}\text { Total } \\
\text { Revenue } \\
\text { (1000SR) }\end{array}$ & $\begin{array}{c}\text { Farm } \\
\text { Area } \\
\text { (Hectare) }\end{array}$ & $\begin{array}{c}\text { Total } \\
\text { Water } \\
\text { (m3) }\end{array}$ & $\begin{array}{c}\text { Total } \\
\text { Labor } \\
\text { (worker) }\end{array}$ & $\begin{array}{l}\text { Organic } \\
\text { fertilizer } \\
\text { (ton) }\end{array}$ & $\begin{array}{c}\text { Chemical } \\
\text { Fertilizer } \\
(\mathrm{kg})\end{array}$ \\
\hline $\begin{array}{c}\text { Standard } \\
\text { Deviation }\end{array}$ & 781 & 6281 & 121 & 1665627 & 30 & 5522 & 24804 \\
\hline Mean & 262 & 2380 & 41 & 595461 & 19 & 2891 & 7917 \\
\hline Minimum & 2 & 19 & 0.1 & 13126 & 2 & 200 & 30 \\
\hline Maximum & 5215 & 42505 & 700 & 9631760 & 174 & 45000 & 218000 \\
\hline $\begin{array}{l}\text { Organic Date } \\
\text { Farms }\end{array}$ & $\begin{array}{l}\text { Total } \\
\text { Yield } \\
\text { (tons) } \\
\end{array}$ & $\begin{array}{c}\text { Total } \\
\text { Revenue } \\
\text { (1000SR) }\end{array}$ & $\begin{array}{c}\text { Farm } \\
\text { Area } \\
\text { (Hectare) }\end{array}$ & $\begin{array}{c}\text { Total } \\
\text { Water } \\
(\mathrm{m} 3) \\
\end{array}$ & $\begin{array}{c}\text { Total } \\
\text { Labor } \\
\text { (worker) }\end{array}$ & $\begin{array}{c}\text { Organic } \\
\text { fertilizer } \\
\text { (ton) }\end{array}$ & \\
\hline $\begin{array}{c}\text { Standard } \\
\text { Deviation } \\
\end{array}$ & 192 & 2387 & 45 & 681222 & 18 & 3942 & \\
\hline Mean & 113 & 1506 & 25 & 407200 & 15 & 2553 & \\
\hline Minimum & 1 & 14 & 0.1 & 9794 & 1 & 200 & \\
\hline Maximum & 810 & 9775 & 200 & 2961616 & 86 & 18700 & \\
\hline
\end{tabular}

\section{Results}

Data reported in Table 2 indicate efficiency estimates for conventional and organic date farms based on farm size. Table 3 shows the distribution of date farms among efficiency measurement ranges. Table 4 presents the impacts of determents on conventional and organic date farm efficiencies. 
Table 2: $\quad$ Efficiency estimations based on date farm size and type.

\begin{tabular}{|l|c|c|c|c|c|c|c|}
\hline $\begin{array}{l}\text { Farm } \\
\text { Type } \\
\text { and area }\end{array}$ & $\begin{array}{c}\text { No. of } \\
\text { Farms }\end{array}$ & $\begin{array}{c}\text { Average } \\
\text { farm } \\
\text { Area }\end{array}$ & $\begin{array}{c}\text { Tech.Effic. } \\
\text { Var.Return } \\
\text { to Scale }\end{array}$ & $\begin{array}{c}\text { Tech. Effic. } \\
\text { Const.Return } \\
\text { to Scale }\end{array}$ & $\begin{array}{c}\text { Scale } \\
\text { Efficiency }\end{array}$ & $\begin{array}{c}\text { Allocative } \\
\text { Efficiency }\end{array}$ & $\begin{array}{c}\text { Cost } \\
\text { Efficiency }\end{array}$ \\
\hline \multicolumn{7}{|c|}{ Conventional farms (Y) } \\
\hline mean & 82 & 41 & 0.63 & 0.47 & 0.76 & 0.66 & 0.40 \\
\hline$>30$ & 13 & 214 & 0.81 & 0.51 & 0.65 & 0.44 & 0.35 \\
\hline $10--30$ & 24 & 15 & 0.67 & 0.54 & 0.81 & 0.70 & 0.46 \\
\hline$<30$ & 45 & 6 & 0.56 & 0.42 & 0.76 & 0.71 & 0.38 \\
\hline \multicolumn{7}{|c|}{ Conventional farms (TR) } \\
\hline mean & 82 & 41 & 0.63 & 0.47 & 0.76 & 0.66 & 0.40 \\
\hline$>30$ & 13 & 214 & 0.81 & 0.51 & 0.65 & 0.44 & 0.35 \\
\hline $10--30$ & 24 & 15 & 0.67 & 0.54 & 0.81 & 0.70 & 0.46 \\
\hline$<30$ & 45 & 6 & 0.56 & 0.42 & 0.76 & 0.71 & 0.38 \\
\hline \multicolumn{7}{|c|}{ Organic Farms (Y) } \\
\hline mean & 49 & 26 & 0.65 & 0.47 & 0.73 & 0.64 & 0.42 \\
\hline$>30$ & 9 & 102 & 0.71 & 0.63 & 0.85 & 0.66 & 0.49 \\
\hline $10--30$ & 11 & 17 & 0.65 & 0.45 & 0.72 & 0.63 & 0.42 \\
\hline$<30$ & 29 & 4 & 0.62 & 0.43 & 0.70 & 0.64 & 0.39 \\
\hline \multicolumn{7}{|l|}{ Organic Farms (TR) } \\
\hline mean & 49 & 26 & 0.59 & 0.40 & 0.68 & 0.63 & 0.39 \\
\hline$>30$ & 9 & 102 & 0.61 & 0.49 & 0.81 & 0.68 & 0.44 \\
\hline $10--30$ & 11 & 17 & 0.62 & 0.40 & 0.66 & 0.55 & 0.35 \\
\hline$<30$ & 29 & 4 & 0.58 & 0.37 & 0.65 & 0.65 & 0.38 \\
\hline
\end{tabular}

Table 3: The distribution of date farms based on efficiency range.

\begin{tabular}{|c|c|c|c|c|c|c|c|c|}
\hline \multirow{3}{*}{ Efficiency\% } & \multicolumn{3}{|c|}{ Conventional date farms } & \multicolumn{4}{c|}{ Organic date farm } \\
\cline { 2 - 10 } & $\begin{array}{c}\text { Tech. Effic. } \\
\text { Var. Return to } \\
\text { Scale }\end{array}$ & \multicolumn{2}{c|}{$\begin{array}{c}\text { Tech. Effic. } \\
\text { Cost Efficiency }\end{array}$} & $\begin{array}{c}\text { Var. Return to } \\
\text { Scale }\end{array}$ & \multicolumn{2}{c|}{ Cost Efficiency } \\
\cline { 2 - 10 } & Farm\# & $\%$ & Farm\# & $\%$ & Farm\# & $\%$ & Farm\# & $\%$ \\
\hline 100 & 10 & 12 & 3 & 4 & 7 & 14 & 4 & 8 \\
\hline $90-99$ & 7 & 9 & 2 & 2 & 0 & 0 & 0 & 0 \\
\hline $80-89$ & 8 & 10 & 2 & 2 & 2 & 4 & 1 & 2 \\
\hline $70-79$ & 16 & 20 & 2 & 2 & 5 & 10 & 0 & 0 \\
\hline $60-69$ & 14 & 17 & 10 & 12 & 4 & 8 & 2 & 4 \\
\hline $50-59$ & 18 & 22 & 16 & 20 & 14 & 29 & 3 & 6 \\
\hline $40-49$ & 7 & 9 & 26 & 32 & 10 & 20 & 3 & 6 \\
\hline $30-39$ & 2 & 2 & 18 & 22 & 4 & 8 & 12 & 24 \\
\hline $20-29$ & 0 & 0 & 3 & 4 & 3 & 6 & 19 & 39 \\
\hline $10-19$ & 0 & 0 & 0 & 0 & 0 & 0 & 4 & 8 \\
\hline $0-9$ & 0 & 0 & 0 & 0 & 0 & 0 & 1 & 2 \\
\hline sum & 82 & 100 & 82 & 100 & 49 & 100 & 49 & 100 \\
\hline
\end{tabular}

\subsection{Efficiency results}

Technical and cost efficiency indices for conventional and organic date farms, based on farm area class, are reported in Table 2. Technical efficiency indexes for large farms were, on average, larger than for small farms. In addition, a higher percentage of large farms were technically efficient. Nonetheless, large farms still had the potential to increase their output by almost $37 \%$ for conventional farms and $35 \%$ for organic farms at current levels of input use. 
Table 4: Determinants of technical, cost, and scale efficiencies.

\begin{tabular}{|c|c|c|c|c|c|c|c|}
\hline \multicolumn{4}{|c|}{ Conventional date farms } & \multicolumn{4}{|c|}{ Organic Date farms } \\
\hline \multicolumn{4}{|c|}{$\mathrm{Lhs}=\mathrm{CE} ; \mathrm{Rhs}=\mathrm{ONE}, \mathrm{W}, \mathrm{L}, \mathrm{TA}, \mathrm{A}, \mathrm{Y}$} & \multicolumn{4}{|c|}{ Lhs $=\mathrm{CE} ; \mathrm{Rhs}=\mathrm{ONE}, \mathrm{W}, \mathrm{L}, \mathrm{TA}, \mathrm{ATA}, \mathrm{YA}$} \\
\hline Variable & Coefficient & $\mathrm{b} / \mathrm{St} . \mathrm{Er}$ & $\mathrm{P}[|\mathrm{Z}|>\mathrm{z}]$ & Variable & Coefficient & $\mathrm{b} / \mathrm{St} . \mathrm{Er}$ & $\mathrm{P}[|\mathrm{Z}|>\mathrm{z}]$ \\
\hline Constant & 0.19046133 & 4.906 & 0.00 & YA & 0.06954623 & 5.165 & 0.00 \\
\hline $\mathrm{W}$ & $.791108 \mathrm{D}-05$ & -4.086 & 0.00 & \multicolumn{4}{|c|}{ Lhs=TE;Rhs=ONE,W,L,TA,ATA,YA } \\
\hline TA & $.828676 \mathrm{D}-04$ & 2.036 & 0.04 & Variable & Coefficient & $\mathrm{b} / \mathrm{St} . \mathrm{Er}$ & $\mathrm{P}[|\mathrm{Z}|>\mathrm{z}]$ \\
\hline A & 0.0586881 & 6.438 & 0.00 & Constant & 0.26681954 & 2.792 & 0.01 \\
\hline $\mathrm{Y}$ & 0.05710732 & 16.697 & 0.00 & W & 480313D-05 & 1.784 & 0.07 \\
\hline \multicolumn{4}{|c|}{ Lhs $=$ TE;Rhs $=$ ONE,W,L,TA,A,Y } & ATA & 0.11028399 & 1.955 & 0.05 \\
\hline Variable & Coefficient & $\mathrm{b} / \mathrm{St} . \mathrm{Er}$ & $\mathrm{P}[|\mathrm{Z}|>\mathrm{z}]$ & YA & 0.04330689 & 2.95 & 0.00 \\
\hline Constant & 0.20791767 & 1.662 & 0.10 & \multicolumn{4}{|c|}{ Lhs $=$ SCALE;Rhs=ONE,W,L,TA,ATA,YA } \\
\hline $\mathrm{W}$ & $.147885 \mathrm{D}-04$ & 2.778 & 0.01 & Variable & Coefficient & $\mathrm{b} / \mathrm{St} . \mathrm{Er}$ & $\mathrm{P}[|\mathrm{Z}|>\mathrm{z}]$ \\
\hline $\mathrm{L}$ & -0.12268435 & -3.732 & 0.00 & Constant & 0.48706003 & 5.899 & 0.00 \\
\hline $\mathrm{Y}$ & 0.05100037 & 5.869 & 0.00 & $\mathrm{~W}$ & $-.608680 \mathrm{D}-05$ & -2.439 & 0.01 \\
\hline \multicolumn{8}{|c|}{ Lhs $=\mathrm{CE} ; \mathrm{Rhs}=\mathrm{ONE}, \mathrm{W}, \mathrm{L}, \mathrm{TA}, \mathrm{A}, \mathrm{TR}$} \\
\hline Variable & Coefficient & $\mathrm{b} / \mathrm{St} . \mathrm{Er}$ & $\mathrm{P}[|\mathrm{Z}|>\mathrm{z}]$ & YA & 0.0780872 & 4.324 & 0.00 \\
\hline Constant & 0.12257241 & 3.413 & 0.00 & \multicolumn{4}{|c|}{ Lhs $=\mathrm{CE} ; \mathrm{Rhs}=\mathrm{ONE}, \mathrm{W}, \mathrm{L}, \mathrm{TA}, \mathrm{ATA}, \mathrm{TR}$} \\
\hline $\mathrm{W}$ & $-.375874 \mathrm{D}-05$ & -2.184 & 0.03 & Variable & Coefficient & $\mathrm{b} / \mathrm{St} . \mathrm{Er}$ & $\mathrm{P}[|\mathrm{Z}|>\mathrm{z}]$ \\
\hline TA & $.469879 \mathrm{D}-04$ & 7.105 & 0.00 & TR & 0.00365389 & 4.062 & 0.00 \\
\hline & & & & \multicolumn{4}{|c|}{ Lhs $=\mathrm{TE} ; \mathrm{Rh} s=\mathrm{ONE}, \mathrm{W}, \mathrm{L}, \mathrm{TA}, \mathrm{ATA}, \mathrm{TR}$} \\
\hline TR & 0.00419638 & 18.049 & 0.00 & Variable & Coefficient & b/St.Er & $\mathrm{P}[|\mathrm{Z}|>\mathrm{Z}]$ \\
\hline \multicolumn{4}{|c|}{ Lhs=TE;Rhs=ONE,W,L,TA,A,TR } & Constant & 0.18245534 & 2.001 & 0.05 \\
\hline Variable & Coefficient & $\mathrm{b} / \mathrm{St} . \mathrm{Er}$ & $\mathrm{P}[|\mathrm{Z}|>\mathrm{z}]$ & TR & 0.00365291 & 3.403 & 0.00 \\
\hline Constant & 0.15903513 & 1.158 & 0.25 & \multicolumn{4}{|c|}{ Lhs $=$ SCALE; Rhs $=$ ONE,W,L,TA,ATA,TR } \\
\hline $\mathrm{W}$ & $.197373 \mathrm{D}-04$ & 3.091 & 0.00 & Variable & Coefficient & $\mathrm{b} / \mathrm{St} . \mathrm{Er}$ & $\mathrm{P}[|\mathrm{Z}|>\mathrm{z}]$ \\
\hline $\mathrm{L}$ & -0.17630566 & -4.375 & 0.00 & Constant & 0.60249504 & 5.598 & 0.00 \\
\hline & & & & $\mathrm{W}$ & $-.102463 \mathrm{D}-04$ & -2.954 & 0.00 \\
\hline & & & & TR & 0.00374934 & 3.182 & 0.00 \\
\hline TR & 0.00344976 & 3.914 & 0.00 & \multicolumn{4}{|c|}{ Lhs $=$ SCALE $;$ Rhs $=$ ONE,W,L,TA,ATA,YA } \\
\hline \multicolumn{4}{|c|}{ Lhs=SCALE;Rhs=ONE,W,L,TA,A,Y } & Variable & Coefficient & $\mathrm{b} / \mathrm{St} . \mathrm{Er}$ & $\mathrm{P}[|\mathrm{Z}|>\mathrm{z}]$ \\
\hline Variable & Coefficient & $\mathrm{b} / \mathrm{St} . \mathrm{Er}$ & $\mathrm{P}[|\mathrm{Z}|>\mathrm{z}]$ & Constant & 0.48706003 & 5.899 & 0.00 \\
\hline Constant & 0.69224372 & 3.569 & 0.00 & $\mathrm{~W}$ & $-.608680 \mathrm{D}-05$ & -2.439 & 0.01 \\
\hline $\mathrm{W}$ & $.166719 \mathrm{D}-04$ & -2.139 & 0.03 & TA & $.433842 \mathrm{D}-04$ & 1.772 & 0.08 \\
\hline $\mathrm{Y}$ & 0.07981826 & 3.489 & 0.00 & YA & 0.0780872 & 4.324 & 0.00 \\
\hline \multicolumn{4}{|c|}{ Lhs=SCALE;Rhs=ONE,W,L,TA,A,TR } & & & & \\
\hline Variable & Coefficient & $\mathrm{b} / \mathrm{St} . \mathrm{Er}$ & $\mathrm{P}[|\mathrm{Z}|>\mathrm{z}]$ & & & & \\
\hline Constant & 0.6322291 & 3.403 & 0.00 & & & & \\
\hline $\mathrm{W}$ & $-.163088 \mathrm{D}-04$ & -1.942 & 0.05 & & & & \\
\hline TR & 0.00761038 & 4.033 & 0.00 & & & & \\
\hline
\end{tabular}


Cost efficiency indices for small and large farms are reported in the Table 2. On average, medium size farms, 10-30 hectares, were more cost efficient than large and small conventional date farms. Cost efficiency indices indicate that large farms had the potential to reduce costs by $65 \%$, while medium and small farms had the potential to reduce costs by $34 \% 62 \%$ respectively, and produce current production. In general, cost minimization indices were considerably lower than their corresponding technical efficiency indices. For organic date farms, large scale farms, more than 30 hectares, are more efficient from technical side, as it can use less inputs by $29 \%$ to produce same output. The small farms are less efficient from both technical and cost efficiency in case of organic date farms. Table 3 has more details about conventional and organic date farms distribution among efficiency ranges. In the case of conventional date farms, $22 \%$ and $20 \%$ of farms have $50-59 \%$ and $70-79 \%$ ranges of technical efficiency. $32 \%$ of conventional date farms have a cost efficiency range of $40-49 \%$. To compare with organic date farm efficiency, $29 \%$ and $20 \%$ of total organic date farms have technical efficiency ranges of 50-59\% and 40-49\% respectively. For $39 \%$ of organic date farms have cost efficiency range $20-29 \%$ only, while $24 \%$ of these farms have 30-39\% cost efficiency estimate range. Farms have full technical and cost efficiency index, $100 \%$, vary based on date farm type, conventional and organic. For technical efficiency, 10 and 7 farms have achieved full efficiency for conventional and organic date farms. Full cost efficiency rate was achieved by 3 conventional and 4 organic date farms. Last results, indicate that $73 \%$ of organic date farms have cost efficiency less than $40 \%$, which support pushing toward policies for supporting organic farming to reduce cost of production. In case of conventional date farms, only $26 \%$ of farms have cost efficiency range of $20-40 \%$. Note that, the use of total revenue instead of farm yield, as dependent variable, would reflect the impact of different date varieties and its prices on efficiency. The results show that efficiency estimates of conventional date farms are not response to change farm yield by farm total revenues, while efficiencies are different in case of organic date farms. These results would be explained by relatively higher price of date varieties produced by organic date farms.

\subsection{Efficiency determinants}

Using the efficiency index measures, as dependent variables, in a series of regressions, applying Tobit Model (Maddala [14]), and relative input use as independent variables would reflect its impacts on date farm efficiency. Results, from Tobit regression, are reported in Table 4. The dependent variable of the Tobit model is a Technical Efficiency (TE), Cost Efficiency (CE), and Scale Efficiency (SE). Explanatory variables in the model include relative input use, such as date farm area to total farm area (A), water use per hectare (W), labor per hectare (L), organic and chemical fertilizer inputs per hectare (OF and CF), in addition to average yield and total revenues ( $\mathrm{Y}$ and TR). Explanatory variables have related the date farm characteristics to efficiency measurements, such as farm scale is related to total farm area, farm specialization is related to relative date farms to total farm area, technology level is related to average number of 
workers per hectare, and average yield and revenues per hectare reflects better farm management. Results in table 4 indicate only the significant impacts of explanatory variables on efficiency indices.

Average water use (W) impacts on technical, cost, and scale efficiencies show a significant negative impact on cost and scale efficiency, see table 4, while that impact was positive in case of technical efficiency with conventional date farms. That means more cost efficient conventional date farms using less water for irrigation, and this is not the case with technical efficient conventional date farms. In the second case, results conclude that technical and cost efficient organic date farm were not affected by water use significantly. Expect in case with scale efficiency, which has a significant negative impact of water use. So, closing the gap between technical efficiencies, constant and variable return to scale, will increasing the efficient use of water as the most scarce recourse. To close that gap, it requires date farms to produce at its maximum capacity. The farm total area (TA), and date farm area to total farm area (A) are considered as explanatory variables in Tobit Model, see table 4. The significant positive impact of farm size on both technical and cost efficiency is considered for conventional and organic date farms. In general, study results encourage increasing date farm size, regardless of its type, to increase its efficiency. Average use of both organic and chemical fertilizers has no significant impacts on efficiency indicators at conventional and organic date farms.

Increasing average water use, in $1000 \mathrm{~m}^{3}$ per hectare, by $10 \%$ will decrease cost efficiency by $0.07 \%$ and scale efficiency by $0.17 \%$ at conventional date farms. When total farm area and average date farm area increase by $10 \%$, cost efficiency at conventional date farms will increase by $0.8 \%$ and $0.58 \%$ respectively. Increasing average date yield per hectare by $10 \%$ will increase cost efficiency by $0.57 \%$, technical efficiency by $0.51 \%$, and scale efficiency by $0.70 \%$ at conventional date farms.

For organic date farms, increasing average water use, in $1000 \mathrm{~m} 3$ per hectare, by $10 \%$ will decrease scale efficiency by $0.61 \%$ and increase technical efficiency by $0.05 \%$. Increasing average yield by $10 \%$ will increase cost efficiency by $0.69 \%$, technical efficiency by $0.43 \%$, scale efficiency by $0.78 \%$ at organic date farms.

\section{Conclusions}

Results of the efficiency analysis point to greater inefficiency on small, conventional and organic date farms. This motivates us to ask why this might be the case? Are small date farms simply inefficient, or do special characteristics of these small farms lead to inefficiencies that might be overcome through improved policies? To address these questions we turn to an analysis of possible sources of inefficiency, such as miss use of inputs. In line with results from the DEA analysis, at conventional and organic date farms, results indicate that small farms are technically and cost inefficient.

1- Efficiency appears to decline with using more irrigation water at the date farm, suggesting increasing returns to scale will support water use rationality. 
In contrast, less water use in irrigation is correlated with higher levels of cost and scale efficiencies.

2- Access to labor per hectare associated with higher technical efficiency, reflects higher date farm technology, as less workers means more Technology.

3- Organic and chemical fertilizers use per hectare is not strongly correlated with technical and cost efficiencies.

4- The role of scale inefficiency is more relevant in organic date-growing farms than in the conventional ones.

To further assess the role of farm size in explaining cost inefficiencies, includes our list of interaction terms. The results underscore a positive association between farm area and cost efficiency, although efficiency falls with higher levels water use on small farms. In addition, smaller farms suffered from greater cost inefficiency when employing relatively more labor. Access to labor is correlated with higher cost efficiency indices but the pattern is statistically weak.

The application of study results would suggest the policy of subsidy or payments to organic producers. While we have not investigated optimal payments, our results do suggest that organic producers are relatively more efficient in organic production than conventional producers would have been in organic production. Thus, it is possible that some welfare gains are obtained as a result of agriculture policy. If the goal of society is to guarantee a stable supply of organic food products, then the policy appears to be working because the payments are not sufficiently large to draw in the less efficient potential organic producers who continue to produce conventionally. If, as the policy suggests, date consumers are willing to pay for organic date but value stable prices then the scheme may be welfare enhancing for date consumers.

This study represents only a partial contribution and that the results cannot lead to generalization. More empirical research needs to be done to provide further information on the "distance" between organic and conventional date farming with respect the whole agricultural system. Prior researches have shown that an established group of organic date farms can be as profitable as conventional date farms under certain circumstances. However, organic date farming systems require a transition period before they are fully established after a changeover from conventional date farming (conversion period). This aspect has not been yet analyzed, but it is on our purpose to develop further analysis in order to better understand some of the main mechanisms that characterized organic date farms acting in the date market.

\section{References}

[1] Farrell, M.J., The Measurement of Productive Efficiency. Journal of the Royal Statistical Society 120(3), pp. 253-290, 1957.

[2] Färe, R., Grosskopf, S. and. Lovell, C. A. K., The Measurement of Efficiency of Production. Boston: Kluwer-Nijhoff Publishing, 1985. 
[3] Ray, S. C., Data Envelopment Analysis: Theory and Techniques for Economics and Operations Research. New York: Cambridge University Press, 2004.

[4] Papadas, C. T. and Dahl, D. C., Technical Efficiency and Farm Size: A Non-Parametric Frontier Analysis. Staff paper P: 91-53, Department of Agricultural and Applied Economics, University of Minnesota, 1991.

[5] Carter, M. R., Identification of the Inverse Relationship between Farm Size and Productivity: An Empirical Analysis of Peasant Agricultural Production. Oxford Economic Papers, New Series 36(1), pp. 131-145, 1984.

[6] Shively, G. E. and. Zelek, C. A., Technical Change, Factor Bias, and Input Adjustments: Panel Data Evidence from the Philippines. Philippine Journal of Development 30(1), pp. 91-110, 2003.

[7] Hoque, A., Farm Size and Economic-Allocative Efficiency in Bangladesh Agriculture. Applied Economics 20, pp. 1353-1368, 1988.

[8] Adesina, A. A., and Djato, K. K., Farm Size, Relative Efficiency and Agrarian Policy in Côte d'Ivoire: Profit Function Analysis of Rice Farms. Agricultural Economics 14, pp. 93-102, 1996.

[9] Tadesse, B. and S. Krishnamoorthy, S. Technical Efficiency in Paddy Farms of Tamil Nadu: An Analysis Based on Farms Size and Ecological Zone, 1997.

[10] Gilligan, D. O., Farm Size, Productivity, and Economic Efficiency: Accounting for Differences in Efficiency of Farms by Size in Honduras. Paper presented at AAEA annual meeting, Salt Lake City, Utah, 1998.

[11] Shafiq, M. and Rehman, T., The Extent of Resource Use Inefficiencies in Cotton Production in Pakistan's Punjab: An Application of Data Envelopment Analysis. Agricultural Economics 22, pp. 321-330, 2000.

[12] Fletschner, D. K. and Zepeda, L., Efficiency of Small Landholders in Eastern Paraguay. Journal of Agricultural and Resource Economics 27(2), pp. $554-572,2002$.

[13] Nyemeck, J., Sylla, K., Diarra, I. and Nyambi, G., Factors Affecting Technical Efficiency among Coffee Farmers in Côte d'Ivoire: Evidence from the Centre West Region. African Development Review 15(1), pp. 66$76,2003$.

[14] Maddala, G., Limited-dependent and Qualitative Variables in Econometrics. New York: Cambridge University Press, 2003. 